\title{
IMPLEMENTASI KURIKULUM KKNI FAKULTAS EKONOMI DAN BISNIS ISLAM UIN SULTAN THAHA SAIFUDDIN JAMBI
}

\author{
Rofiqoh Ferawati \\ Universitas Islam Negeri Sultan Thaha Saifuddin Jambi \\ e-mail: rofiqohferawati@gmail.com
}

\begin{abstract}
The era of sustainable development caused many changes including the education sector. One of the objectives of the 17 goals of sustainable development is quality oof education. Quality education is to ensure quality education that is decent and inclusive and encourages lifelong learning opportunities for everyone and education that must be able to anticipate the development of the labor market and the development of science-based society. Therefore, innovations in various methods and educational models must also be developed. To overcome this, the Ministry of National Education designed and established a curriculum known as the Indonesian Qualification Framework (KKNI). Faculty of Islamic Economics and Business (FEBI) is one of the pilot project for the KKNI curriculum at the Islamic State University (UIN) of Sultan Thaha Saifuddin Jambi. The purpose of this study was to determine the implementation of the KKNI curriculum using qualitative methods. This study resulted that KKNI is designed very well and in accordance with the provisions of laws and learning outcomes that were designed in line with the vision and mission of UIN and FEBI in its implementation $88 \%$ of the 110 respondents said that the KKNI had been implemented properly and well.
\end{abstract}

Keywords: Implementation, Curriculum, Indonesian Qualification Framework.

\begin{abstract}
Abstrak
Era pembangunan berkelanjutan menyebabkan banyak perubahan tidak terkecuali sektor pendidikan. Salah satu tujuan dari 17 tujuan pembangunan berkelanjutan yaitu pendidikan berkualitas. Pendidikan yang berkualitas yaitu memastikan pendidikan berkualitas yang layak dan inklusif serta mendorong kesempatan belajar seumur hidup bagi semua orang dan pendidikan yang harus dapat mengantisipasi perkembangan pasar kerja dan perkembangan masyarakat berbasis ilmu pengetahuan. Oleh karena itu inovasi berbagai metoda dan model pendidikan harus juga dikembangkan. Untuk mengatasi hal tersebut maka kemendiknas merancang dan menetapkan kurikulum yang dikenal dengan nama Kerangka Kualifikasi Nasional Indonesia (KKNI). Fakultas Ekonomi dan Bisnis Islam (FEBI) adalah salah satu fakultas pilot project untuk kurikulum KKNI di Universitas Islam Negeri (UIN) Sultan Thaha Saifuddin Jambi. Tujuan penelitian ini untuk mengetahui Implementasi kurikulum KKNI dengan menggunakan metode kualitatif. Penelitian ini
\end{abstract}

Nur El-Islam, Volume 5, Nomor 2, Oktober 2018 
menghasilkan bahwa KKNI yang dirancang sudah sangat baik dan sesuai dengan ketentuan undang-undang dan learning outcomes yang dirancang sejalan dengan visi dan misi UIN dan FEBI. Dalam implementasinya $88 \%$ dari 110 responden mengatakan bahwa KKNI telah dilaksanakaan berjalan dan dengan baik.

Kata kunci: Implementasi, Kurikulum, KKNI.

\section{A. Pendahuluan}

\section{Latar Belakang Penelitian}

Era pembangunan berkelanjutan menyebabkan banyak perubahan tidak terkecuali sektor pendidikan. Tujuan pembangunan berkelanjutan yang dibuat untuk menjawab tuntutan kepemimpinan dunia dalam mengatasi masalah kemiskinan, kesenjangan dan perubahan iklim dalam bentuk aksi nyata ditargetkan akan dicapai pada tahun 2030 yaitu sebanyak 17 tujuan dengan 169 capaian yang terukur dengan menentapkan rangkaian target yang bisa diaplikasikan secara universal serta dapat diukur dalam menyeimbangkan tiga dimensi pembangunan berkelanjutan yaitu lingkungan, sosial dan ekonomi. ${ }^{1}$ Salah satu tujuan dari 17 tujuan pembangunan berkelanjutan yaitu pendidikan berkualitas. Pendidikan yang berkualitas yaitu memastikan pendidikan berkualitas yang layak dan inklusif serta mendorong kesempatan belajar seumur hidup bagi semua orang dan pendidikan yang harus dapat mengantisipasi perkembangan pasar kerja dan perkembangan masyarakat berbasis ilmu pengetahuan.

Oleh karena itu inovasi berbagai metoda dan model pendidikan harus juga dikembangkan (UNESCO, 2006). Komparasi mutu antar negara merupakan tantangan bagi dunia pendidikan diataranya adalah mobilitas mahasiswa dan tenaga kerja antar negara. Untuk itu diperlukan kesepahaman masyarakat internasional dalam hal kualifikasi ketenagakerjaan. Setiap negara peserta konvensi memerlukan suatu sistem kualifikasi ketenagakerjaan yang dapat

${ }^{1}$ https://id.wikipedia.org/wiki/Tujuan_Pembangunan_Berkelanjutan diakses 14 Desember 2018 
dipahami bersama yang disebut kerangka kualifikasi. ${ }^{2}$ Kerangka kualifikasi merupakan suatu instrument yang mengklasifikasikan kualifikasi seseorang berdasrkan seperangkat kriteria yang dikaitkan dengan jenjang capaian pembelajaran (learning outcomes) yang telah diperolehnya. ${ }^{3}$

Untuk mencapai kesetaraan kualifikasi dari semua luaran pendidikan dan pelatihan di Indonesia harus dapat mengantisipasi 4 (empat) hal pokok yaitu sikronisasi kebijakan lintas kementerian serta antar lembaga atau asosiasi yang terkait dengan ketenagakerjaan, penyelarasan mutu capaian pembelajaran dari institusi atau lembaga penyelenggara pendidikan dan pelatihan, koordinasi dan sinkronisasi lembaga-lembaga penjaminan mutu yang telah ada maupun yang akan dikembangkan kemudian menjamin terbentuknya kerjasama dan komunikasi yang berkesinambungan antar ketenagakerjaan di Indonesia. ${ }^{4}$

Untuk mengatasi hal tersebut, pada akhir tahun 2009 Direktorat Direktorat Jenderal Pendidikan Tinggi KEMENDIKBUD, melalui kegiatan yang dikembangkan di dalam lingkungan Direktorat Pembelajaran dan Kemahasiswaan (BELMAWA), mengambil inisiatif yang sejalan dengan gagasan Direktorat Bina Instruktur dan Tenaga Kepelatihan, KEMENNAKERTRANS merancang dan menetapkan kurikulum yang dikenal dengan nama Kerangka Kualifikasi Nasional Indonesia (KKNI). ${ }^{5}$

KKNI diatur dalam Peraturan Presiden Republik Indonesia Nomor 8 tahun 2012. KKNI merupakan perwujudan mutu dan jati diri bangsa Indonesia terkait dengan sistem pendidikan nasional, sistem pelatihan kerja nasional dan system penilaian kesetaraan nasional, yang dimiliki Indonesia untuk menghasilkan sumber daya manusia dari capaian pembelajaran yang dimiliki setiap insan pekerja Indonesia dalam menciptakan hasil karya serta kontribusi yang

${ }^{2}$ Direktorat Jendral Pembelajaran dan Kemahasiswaan, Kementerian Riset, Teknologi dan Pendidikan Tinggi RI, Dokumen 001 KKNI, (Ristek Dikti, 2015), h. 2

${ }^{3}$ Ibid. h. 2

${ }^{4}$ Ibid. h. 3

${ }^{5}$ Ibid. h. 4 
bermutu di bidang pekerjaannya masing-masing. Prinsip dasar yang dikembangkan dalam KKNI adalah menilai unjuk kerja seseorang dalam aspek-aspek keilmuan, keahlian dan keterampilan sesuai dengan capaian pembelajaran (learning putcomes) yang diperoleh melalui proses Pendidikan, pelatihan atau pengalaman yang telah dilampauinya, yang setara dengan deskriptor kualifikasi untuk suatu jenjang tertentu. Terkait dengan proses pendidikan, capaian pembelajaran merupakan hasil akhir atau akumulasi proses peningkatan keilmuan, keahlian dan keterampilan seseorang yang diperoleh melalui pendidikan formal, informal atau nonformal.

Dalam arti luas, capaian pembelajaran juga diartikan sebagai hasil akhir dari suatu proses peningkatan kompetensi atau karir seseorang selama bekerja. Prinsip dasar ini sesuai dengan pendekatan yang dilakukan oleh negara-negara lain dalam mengembangkan kerangka kualifikasi masing-masing. Secara umum KKNI diharapkan dapat melahirkan suatu sistem penyetaraan kualifikasi ketenagakerjaan di Indonesia dan memiliki peran yaitu KKNI harus mampu secara komprehesif dan berkeadilan menampung kebutuhan semua pihak yang terkait dengan ketenagakerjaan serta memperoleh kepercayaan masyarakat luas, KKNI diharapkan memiliki jumlah jenjang dan deskripsi kualifikasi yang jelas dan terukur serta secara transparan dapat dipahami oleh pihak penghasil dan pengguna tenaga kerja baik di tingkat nasional, regional maupun internasional, KKNI yang dikembangkan harus bersifat lentur (flexible) sehingga dapat mengatisipasi perkembangan ilmu pengetahuan dan teknologi, kebutuhan keilmuan, keahlian dan keterampilan di tempat kerja serta selalu dapat diperbaharui secara berkelanjutan.

KKNI menyediakan sembilan jenjang kualifikasi, dimulai dari Kualifikasi jenjang 1 sebagai kualifikasi terendah dan kualifikasi jenjang 9 sebagai kualifikasi tertinggi. Penetapan jenjang 1 sampai 9 dilakukan melalui pemetaan komprehensif kondisi ketenagakerjaan di Indonesia ditinjau dari sisi penghasil (supply push) maupun pengguna (demand pull) tenaga kerja.

Standar dosen dan tenaga kependidikan untuk S1 adalah berkualifikasi akademik paling rendah lulusan magister atau magister 
terapan yang relevan dengan program studi, dan dapat menggunakan dosen bersertifikat profesi yang relevan dengan program studi dan berkualifikasi paling rendah setara dengan jenjang KKNI. Standar sarana dan prasarana, standar pengelolaan pembelajaran, standar pembiayaan pembelajaran juga diatur dalam Peraturan Menteri ini.

Fakultas Ekonomi dan Bisnis Islam (FEBI) adalah salah satu fakultas pilot project untuk kurikulum KKNI di Universitas Islam Negeri (UIN) Sultan Thaha Saifuddin Jambi. Fakultas ini diberikan mandat sebagai pilot project untuk kurikulum KKNI. Hal ini didasarkan dari latar belakang usia dosen FEBI yang masih relatif muda dan energik. Hasil wawancara dan observasi awal dengan dosen di FEBI diperoleh bahwa implementasi kurikulum KKNI memiliki banyak permasalahan, diantaranya adalah kurangnya sosialisasi tentang kurikulum KKNI, serta kurangnya pelatihan tentang kurikulum KKNI dan pembobotan SKS yang menjadi besar dikarenakan besarnya beban dan dalamnya pemahaman yang harus dipahami untuk mata kuliah tertentu. Hasil wawancara dan observasi awal yang telah dilakukan dapat kita pahami bahwa implementasi Kurikulum KKNI masih banyak menemui kendala. Banyaknya masalah yang timbul dalam implementasi Kurikulum KKNI ini sehingga menimbulkan berbagai persepsi. Berdasarkan pada uraian di atas maka peneliti tertarik untuk mengkaji untuk mengetahui Implementasi kurikulum KKNI di FEBI.

\section{Kajian Teori}

a. Kurikulum

Secara umum, kurikulum merupakan gambaran gagasan pendidikan yang diekspresikan dalam praktik. Kurikulum didefinisikan sebagai seluruh program pembelajaran yang terencana dalam institusi pendidikan. Kurikulum menurt Saylor, Alexander, lewis, Schiro dan Robert Gagne sebagaimana dikatakan Ahmad dkk merupakan kegiatan yang disajikan di kampus/sekolah berupa instrument, rangkaian unit materi belajar yang telah disusun, dan seperangkat rencana yang berisi pengalaman belajar agar dapat merealisasikan bakatnya dan menembangkan taraf hidup dalam 
masyarakat berdasarkan kemampuan yang dimiliki sebelumnya. ${ }^{6}$ Pondasi kurikulum meliputi kemasan tata nilai (values) dan kepercayaan (beliefs) tentang apa yang harus diketahui mahasiswa dan bagaimana caranya mahasiswa dapat memperoleh dan atau menguasai pengetahuan. ${ }^{7}$ Kurikulum juga harus dikemas dalam bentuk yang mudah dikomunikasikan kepada pihak-pihak yang terkait dalam institusi pendidikan, harus terbuka untuk dikritik dan harus mudah ditransformasikan dalam praktik. ${ }^{8}$

Tantangan perkembangan IPTEKS terus memotivasi untuk dilakukannya perubahan dan penyesuaian kurikulum. Demikian pula perkembangan kebutuhan masyarakat dan pemangku kepentingan (stakeholder) ikut mendorong untuk melakukan pengembangan kurikulum. Hal ini berkaitan dengan Undang-undang RI tentang Sistem Pendidikan Nasional, Nomor 20/2003 Bab X, Pasal 38, ayat 3 \&amp; 4 dinyatakan bahwa kurikulum pendidikan tinggi yang bersangkutan dengan mengacu pada Standar Nasional Pendidikan untuk setiap program studi. Kerangka dasar dan struktur kurikulum pendidikan tinggi dikembangkan oleh perguruan tinggi yang bersangkutan dengan mengacu pada Standar Nasional Pendidikan untuk setiap program studi. Shane mengilustrasikan pengembangan kurikulum sebagai sebuah proses perubahan sebagaimana yang terjadi dalam revolusi sains versi Thomas Khun. Visualisasi perubahan kurikulum versi teori revolusi sains Thomas Khun sebagai berikut:

\footnotetext{
${ }^{6}$ Ahmad, dkk, Pengembangan Kurikulum (Bandung: CV. Pustaka Setia, 1998), h.10-14

${ }^{7}$ Murray Print, Curriculum Development and Design (second edition), (Sidney: Allen \& Unwin, 1992) Disadur dari Prideux D. ABC of leraning and teaching in medicine: Curriculum design. BMJ 2003; 326: 268-270

8 Harsono, Pengantar Problem-based Learning. Edisi kedua, (Medika-Fakultas Kedokteran Universitas Gadjah Mada, 2005), h. 23
} 


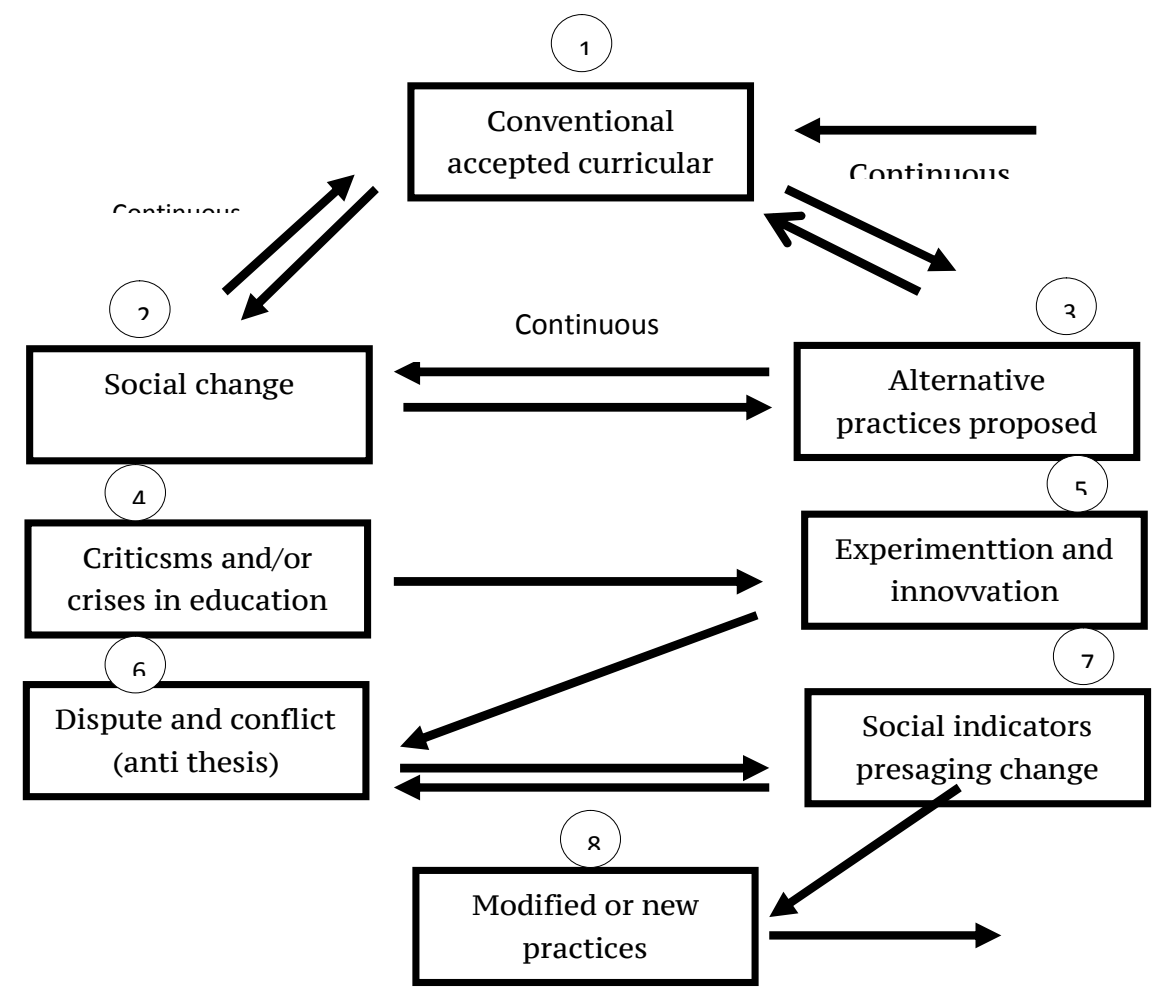

Gambar 1. Alur perubahan kurikulum Thomas Khun ${ }^{9}$

\section{b. Pengembangan Kurikulum Berbasis pada KKNI}

Pengembangan kurikulum dilakukan mengacu pada KKNI, karena pendidikan dapat terstandar melalui KKNI. Alur penyusunan kurikulum berbasis KKNI:

1. Tahap Perancangan Kurikulum ${ }^{10}$

${ }^{9}$ Khun, Thomas, The Structure of Scientific Revolution. $3^{\text {rd }}$ ed. (Chicago, IL: University of Chicago Press, 1996) h. 109-111.

Nur El-Islam, Volume 5, Nomor 2, Oktober 2018 
a. Perumusan Capaian Pembelajaran Lulusan (CPL)

Tahapan penyusunan CPL yaitu:

- Penetapan Profil Lulusan

- Penetapan Kemampuan yang diturunkan dari profil

- Merumuskan CPL

b. Pembentukan mata kuliah

Tahapan pembentukan mata kuliah ini dibagi dalam dua kegiatan pertama pemilihan bahan kajian dan kedua secara simultan juga dilakukan penyusunan matriks antara bahan kajian dengan rumusan CPL yang telah ditetapkan. Rincinya sebagai berikut:

- Pemilihan bahan kajian \& penyusun matriks anatara bahan kajian dengan rumusan CPL (materi pelanjaran)

- Penetapan mata kuliah

- Penetapan besarnya sks mata kuliah

c. Penyusunan mata kuliah (kerangka kurikulum)

Tahap ini adalah menyusun mata kuliah ke dalam semester. Penyusunan mata kuliah adalah bagaimana membangun struktur kurikulum. Membangun struktur kurikulum ada dua model yaitu:

- serial = pertimbangan struktur atau logika keilmuan yang dianut (berdasar logika keilmuan., asumsi dasar, ada prasarat, parsial, integrasi diakhir)

- Paralel = Pertimbangan proses pembelajaran (berdasar strategis pembelajaran, prasyarat dielimir dalam proses pembelajaran, integrase lebih awal).

2. Tahap perancangan Pembelajaran ${ }^{11}$

a. Mengidentifikasi CPL yang dibebankan pada mata kuliah

b. Merumuskan CPMK yang bersifat spesifik terhadapa matakuliah berdasarkan CPL yang dibebankan pada $\mathrm{MK} \mathrm{Bb}$

${ }^{10}$ Direktorat Jendral Pembelajaran dan Kemahasiswaan, Kementerian Riset, Teknologi dan Pendidikan Tinggi RI. Panduan Penyusunan Kurikulum Pendidikan Tinggi (Ristek 2016), h. 7- 18

${ }^{11}$ Ibid. h. 21-32. 
c. Merumuskan sub-CPMK yang merupakan kemampuan akhir yang direncanakan pada tiap tahap pembelajran \& dan dirumyskan berdasarkan CPMK

d. Analisis pembelajaran (analisis tiap tahapan belajar)

e. Menentukan indicator dan kriteria sub CPMK

f. Mengembangkan instrument penilaian pembelajaran berdasarkan indicator pencapain kemampuan akhir tiap tahapan belajar

g. Memilih \& mengembangkan model/metode/ strategi

h. Mengembangan materi pembelajaran

i. Mengembangkan \& melakukan evaluasi pembelajaran

- Merumuskan CPMK

- Menyusun RPS

- Proses Pembelajaran

- Penilaian Pembelajaran

3. Tahap Evaluasi Program Pembelajaran ${ }^{12}$

Mengubah angket kepada mahasiswa sebelum kegiatan pembelajaran selesai disetiap semester, Tabulasi, Analisis

Perumusan kompetensi lulusan merupakan tahap setelah ditentukannya profil lulusan. Penentuan kompetensi lulusan merupakan titik tolak dalam menentukan kelancaran dan keberhasilan pengembangan tahap-tahap berikutnya dalam pengembangan kurikulum. Mengacu makna kompetensi sebagai seperangkat tindakan cerdas, penuh tanggung jawab yang dimiliki seseorang sebagai syarat untuk dianggap mampu oleh masyarakat dalam melaksanakan tugastugas di bidang pekerjaan tertentu. ${ }^{13}$

\section{B. Pembahasan}

1. Implementasi Kurikulum

UIN STS Jambi menjadikan Islamic entrepreneurship sebagai distingsi keilmuan yang diaplikasikan melalui paradigm sungai ilmu. Islamic Entrepreneurship "Entrepreneur Based on Spiritual-

\footnotetext{
${ }^{12}$ Ibid., h. 39

${ }^{13}$ SK Mendiknas Nomor. 045/U/2002.
} 
Professionalism" Entrepreneur atau kewirausahaan pada dasarnya bermakna effort atau upaya, sehingga tidak dapat dikonotasikan sebagai bisnis belaka. Jiwa dan semangat kewirausahaan bukan hanya milik para pengusaha (business-man) saja, melainkan juga milik para profesional dan peran apa saja dalam berbagai fungsi yang berbeda, apakah itu profesi guru/dosen, murid/mahasiswa, dokter, tentara, polisi, dan sebagainya. Oleh sebab itu, ia tidak bersifat given atau keahlian genetik; melainkan sesuatu yang dapat dipelajari dan dilakukan oleh siapapun. Oleh sebab itu, UIN STS Jambi berupaya membentuk mentalitas kewirausahaan yang berbasiskan pada profesionalisme-spiritual (entrepreneur based on spiritualprofessionalism).

Nilai-nilai dasar profesionalisme-spiritulitas tersebut diwujudkan dalam format kurikulum UIN STS Jambi termasuk FEBI dengan tetap mengacu pada Standar Nasional Perguruan Tinggi (SNPT) dan Kerangka Kualifikasi Nasional Indonesia (KKNI). Ada dua model pendekatan yang dikembangkan, yaitu: Teaching System Model (TSM) dan Experience System Model (ESM). Pendekatan TSM diaplikasikan melalui dua metode, yaitu: membentuk satu mata kuliah tertentu (Islamic Entrepreneurship) di seluruh program studi, dan memasukkan nilai-nilai Islamic entrepreneurship ke dalam materi perkuliahan.

FEBI sebagai fakultas yang merupakan pilot project dalam pelaksanaan kurikulum KKNI telah merancang kurikulum KKNI sesuai dengan undang-undang. Mahasiswa FEBI angkatan 2015 merupakan angkatan pertama yang mendapatkan kurikulum KKNI. Rincian kurikulum KKNI yang dirancang dan diimplementasikan di FEBI secara detil disajikan berikut ini. Untuk deskripsi level sesuai dengan aturan untuk jenjang S1 berada pada level 6, dengan deskripsi secara umum sama semua untuk prodi apapun.

\section{a. Deskripsi Umum}

Sesuai dengan ideologi Negara dan budaya Bangsa Indonesia, maka implementasi sistem pendidikan nasional yang dilakukan di Indonesia pada setiap level kualifikasi pada KKNI mencakup proses 
yang membangun karakter dan kepribadian manusia Indonesia sebagai berikut:

1. Bertakwa kepada Tuhan Yang Maha Esa.

2. Memiliki moral, etika dan kepribadian yang baik di dalam menyelesaikan tugasnya.

3. Berperan sebagai warga negara yang bangga dan cinta tanah air serta mendukung perdamaian dunia.

4. Mampu bekerjasama dan memiliki kepekaan sosial dan kepedulian yang tinggi terhadap masyarakat dan lingkungannya.

5. Menghargai keanekaragaman budaya, pandangan, kepercayaan dan agama serta pendapat/temuan original orang lain.

6. Menjunjung tinggi penegakan hukum serta memiliki semangat untuk mendahulukan kepentingan bangsa serta masyarakat luas.

\section{b. Deskripsi Kualifikasi Level 6 Jenjang Sarjana (S1)}

Untuk deskripsi kualifikasi masing-masing prodi berbeda sesuai dengan learning outcomes yang akan dicapai. Untuk FEBI sendiri secara detil deskripsi spesifik disajikan pada tabel berikut.

\begin{tabular}{|c|c|c|c|}
\hline No & $\begin{array}{l}\text { Unsur } \\
\text { Kualifikasi } \\
\text { Kerja }\end{array}$ & $\begin{array}{l}\text { Deskripsi } \\
\text { Generik }\end{array}$ & Deskripsi Spesifik \\
\hline 1 & $\begin{array}{l}\text { Kemampuan } \\
\text { Kerja }\end{array}$ & $\begin{array}{l}\text { Mampu } \\
\text { mengaplikasikan } \\
\text { bidang } \\
\text { keahliannya dan } \\
\text { memanfaatkan } \\
\text { ilmu } \\
\text { pengetahuan, } \\
\text { teknologi, dan } \\
\text { atau seni pada } \\
\text { bidangnya dalam } \\
\text { penyelesaian } \\
\text { masalah serta }\end{array}$ & $\begin{array}{l}\text { 1. } \text { Mampu menerapkan } \\
\text { teori-teori } \\
\text { syariah ekonomi } \\
\text { teknologi informasi } \\
\text { dan komunikasi } \\
\text { 2. Mampu } \\
\text { memanfaatkan } \\
\text { perkembangan ilmu } \\
\text { pengetahuan dan } \\
\text { teknologi informasi } \\
\text { ekonomi syariah } \\
\text { berbasis teknologi }\end{array}$ \\
\hline
\end{tabular}




\begin{tabular}{|c|c|c|c|}
\hline & & $\begin{array}{l}\text { mampu } \\
\text { beradaptasi } \\
\text { terhadap situasi } \\
\text { yang dihadapi. }\end{array}$ & $\begin{array}{l}\text { informasi dan } \\
\text { komunikasi dalam } \\
\text { menyelesaikan } \\
\text { berbagai masalah } \\
\text { pembelajaran } \\
\text { Ekonomi Syariah di } \\
\text { sekolah/madrasah } \\
\text { 3. Mampu beradaptasi } \\
\text { terhadap situasi yang } \\
\text { dihadapi terkait } \\
\text { dengan dinamika } \\
\text { sosial-budaya, } \\
\text { ekonomi dan politik } \\
\text { serta tantangan global } \\
\text { dalam ekonomi } \\
\text { syariah. }\end{array}$ \\
\hline 2 & $\begin{array}{l}\text { Penguasaan } \\
\text { Pengetahuan }\end{array}$ & $\begin{array}{l}\text { Menguasai } \\
\text { konsep teoritis } \\
\text { bidang } \\
\text { pengetahuan } \\
\text { tertentu secara } \\
\text { umum ran } \\
\text { konsep teoretis } \\
\text { bagian khusus } \\
\text { dalam bidang } \\
\text { pengetahuan } \\
\text { tersebut secara } \\
\text { mendalam, serta } \\
\text { mampu } \\
\text { memformulasikan } \\
\text { penyelesaian } \\
\text { secara prosedural }\end{array}$ & 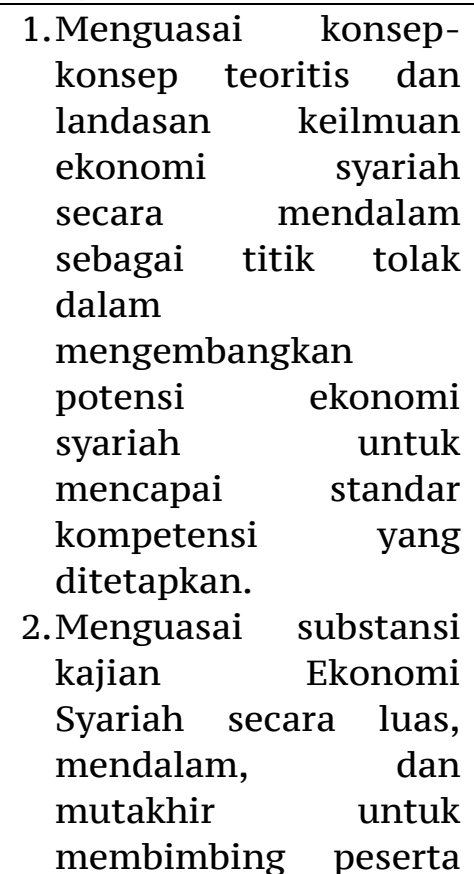 \\
\hline
\end{tabular}




\begin{tabular}{|c|c|c|c|}
\hline & & & 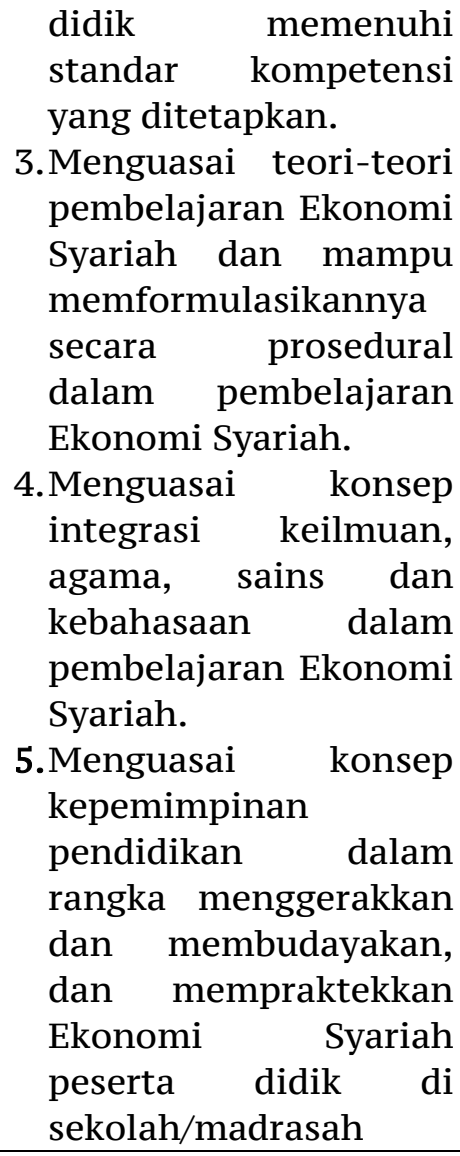 \\
\hline 3 & $\begin{array}{l}\text { Kemampuan } \\
\text { Manajerial }\end{array}$ & $\begin{array}{l}\text { Mampu } \\
\text { mengambil } \\
\text { keputusan yang } \\
\text { tepat berdasarkan } \\
\text { analisis informasi } \\
\text { dan data dan } \\
\text { mampu } \\
\text { memberikan } \\
\text { petunjuk dalam } \\
\text { memilih berbagai }\end{array}$ & $\begin{array}{l}\text { 1. Mampu mengambil } \\
\text { keputusan yang tepat } \\
\text { dan strategis dalam } \\
\text { ekonomi syariah } \\
\text { berdasarkan analisis } \\
\text { informasi dan data } \\
\text { serta hasil penelitian } \\
\text { 2. Mampu memberikan } \\
\text { petunjuk dan langkah- } \\
\text { langkah pemecahan }\end{array}$ \\
\hline
\end{tabular}




\begin{tabular}{|c|c|c|c|}
\hline & & $\begin{array}{l}\text { alternatif solusi } \\
\text { secara mandiri } \\
\text { dan kelompok }\end{array}$ & $\begin{array}{l}\text { berbagai masalah } \\
\text { ekonomi syariah untuk } \\
\text { memperoleh hasil } \\
\text { pembelajaran yang } \\
\text { bermutu dan maksimal } \\
\text { dalam pembentukan } \\
\text { prilaku keagamaan. } \\
\text { 3. Mampu memetakan } \\
\text { wacana dan fenomena } \\
\text { kebahasaan (ekonomi) } \\
\text { serta isu-isu } \\
\text { kontemporer dalam } \\
\text { ekonomi syariah dan } \\
\text { konvensional untuk } \\
\text { dijadikan sebagai dasar } \\
\text { dalam pengembangan } \\
\text { ekonomi syariah. }\end{array}$ \\
\hline 4 & $\begin{array}{l}\text { Tanggung } \\
\text { Jawab } \\
\text { Manajerial }\end{array}$ & \begin{tabular}{l}
\multicolumn{2}{l}{ Bertanggung } \\
jawab pada \\
pekerjaan sendiri \\
dan dapat diberi \\
tanggung jawab \\
atas pencapaian \\
hasil \\
organisasi
\end{tabular} & $\begin{array}{l}\text { 1. Bertanggungjawab dan } \\
\text { dapat diberi } \\
\text { tanggungjawab } \\
\text { terhadap pelaksanaan } \\
\text { pembelajaran ekonomi } \\
\text { yang efektif, produktif, } \\
\text { bermakna, dan } \\
\text { berlandaskan nilai- } \\
\text { nilai kemanusiaan } \\
\text { dalam masyarakat } \\
\text { multi bahasa baik } \\
\text { secara mandiri } \\
\text { maupun dengan } \\
\text { kemitraan tugas } \\
\text { 2. Mampu menyesuaikan } \\
\text { diri secara tepat dalam } \\
\text { menjalankan tugan } \\
\text { pembelajaran ekonomi }\end{array}$ \\
\hline
\end{tabular}




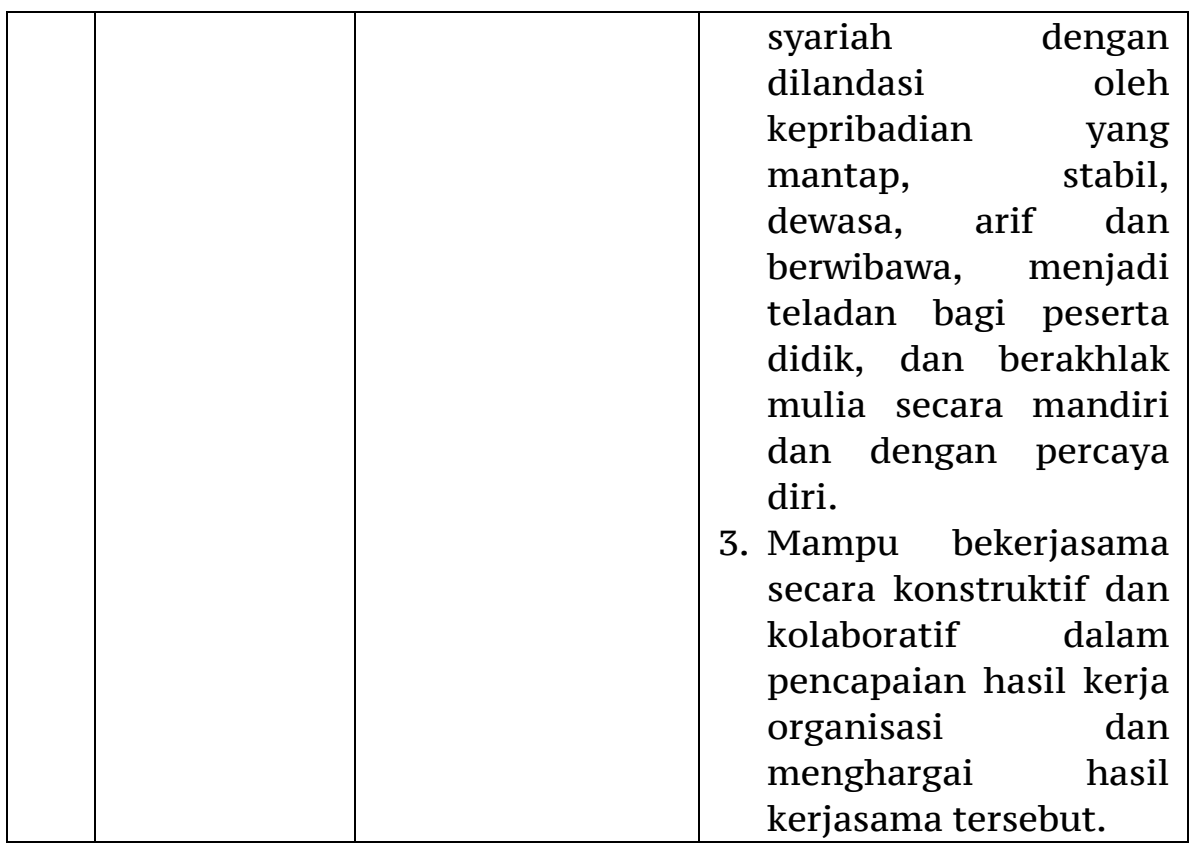

c. Capaian Pembelajaran (Learning Outcome)

a) Capaian Pembelajaran Bidang Sikap dan Tata Nilai

Lulusan prodi Ekonomi Syariah wajib memiliki sikap dan tata nilai sebagai berikut:

1. Bertakwa kepada Tuhan yang Maha Esa dan mampu menunjukkan sikap religius.

2. Menjunjung tinggi nilai kemanusiaan dalam menjalankan tugas berdasarkan agama, moral dan etika.

3. Berkontribusi dalam peningkatan mutu kehidupan masyarakat, berbangsa, bernegara dan kemajuan peradaban berdasarkan pancasila.

4. Berperan sebagai warga negara yang bangga dan cinta tanah air, memiliki nasionalisme serta bertanggung jawab pada bangsa dan negara. 
5. Menghargai keanekaragaman budaya, pandangan, agama dan kepercayaan serta pendapat atau temuan rasional orang lain.

6. Bekerjasama dan memiliki kepekaan sosial serta kepedulian terhadap masyarakat dan lingkungan.

7. Taat hukum dan disiplin dalam kehidupan bermasayarakat dan bernegara.

8. Menginternalisasikan nilai, norma dan etika akademik

9. Menunjukkan sikao bertanggung jawab atas pekerjaan di bidang keahliannya secara mandiri.

10. Menginternasisasikan semangat kemandirian, kejuangan dan kewirausahaan

11. Mampu menjaga kerahasiaan konsumen

12. Istiqomah bertransaksi secara syariah.

b). Capaian Pembelajaran Bidang Pengetahuan

1. Deskripsinya yaitu Lulusan Program Studi Ekonomi Syariah FEBI UIN STS Jambi jenjang sarjana (level 6 dalam KKNI) wajib memiliki pengetahuan sebagai berikut:

2. Memahami proses bisnis dan lingkungan bisnis syariah.

3. Mampu melakukan perancangan usaha dan mengimplementasikan-nya dalam praktek bisnis.

4. Memahami etika dan komunikasi dalam bisnis sesuai nilainilai Islam.

5. Mampu menganalisis informasi keuangan dan pengambilan keputusan manajemen.

6. Mampu memanfaatkan teknologi informasi untuk memudahkan pekerjaan.

7. Mampu bekerja sama dalam tim.

8. Mampu mengelola organisasi.

9. Memahami kondisi perekonomian global (makro, industri dan moneter) yang melingkupi lembaga keuangan Islam.

10. Memahami kaidah fikih dan ushul fikih dalam mengambil keputusan di bidang kebijakan lembaga keuangan Islam.

11. Mampu berfikir kreatif dan inovatif dalam memberikan solusi 
terhadap masalah-masalah (problem solving \& creative skills).

12. Mampu menyampaikan pendapat secara jelas baik secara lisan maupun tulisan (communication skills).

13. Memahami kondisi perekonomian global (makro, industri dan moneter) yang melingkupi lembaga keuangan swasta maupun publik Islam.

14. Mampu menjalin networking dengan berbagai pihak yang terkait bidang kerjanya.

15. Mampu mengembangkan dan mengaplikasikan ide-ide kreatif.

16. Mampu bersikap sesuai etika profesi.

17. Mampu menyusun laporan keuangan perusahaan.

18. Mampu menjalankan tata kelola keuangan perusahaan.

19. Mampu menyusun, menganalisis dan mengevaluasi anggaran.

20. Mampu mengelola SDM (analisis jabatan, sistem imbalan, model penilaian kinerja).

c). Capaian Pembelajaran Bidang Keterampilan Umum

Lulusan Program Studi Ekonomi Syariah jenjang sarjana (level 6 dalam KKNI) wajib memiliki kekerampilan umum sebagai berikut :

1. Mampu menerapkan pemikiran logis, kritis, sistematis, dan inovatif dalam konteks pengembangan atau implementasi ilmu pengetahuan dan teknologi yang memperhatikan dan menerapkan nilai humaniora yang sesuai dengan keahlian.

2. Mampu menunjukkan kinerja mandiri, bermutu, dan terukur.

3. Mampu mengkaji implikasi pengembangan atau implementasi ilmu pengetahuan teknologi yang memperhatikan dan menerapkan nilai humaniora sesuai dengan keahliannya berdasarkan kaidah, tata cara dan etika ilmiah dalam rangka menghasilkan solusi, gagasan, desain atau kritik seni, menyusun deskripsi saintifik hasil kajiannya dalam bentuk skripsi atau laporan tugas akhir, dan mengunggahnya dalam laman perguruan tinggi; menyusun deskripsi saintifik hasil kajian tersebut di atas dalam bentuk skripsi atau laporan 
tugas akhir, dan mengunggahnya dalam laman perguruan tinggi.

4. Mampu menyusun deskripsi saintifik hasil kajian tersebut di atas dalam bentuk skripsi atau laporan tuags akhir dan mengunggahnya dalam laman perguruan tinggi.

5. Mampu mengambil keputusan secara tepat dalam konteks penyelesaian masalah di keahliannya di berdasarkan hasil analisis informasi dan data.

6. Mampu memelihara dan mengembangkan jaringan kerja dengan pembimbing, kolega, sejawat baik di dalam maupun di luar lembaganya.

7. Mampu bertanggungjawab atas pencapaian hasil kerja kelompok dan melakukan supervisi dan evaluasi terhadap penyelesaian pekerjaan yang ditugaskan kepada pekerja yang berada di bawah tanggungjawabnya.

8. Mampu melakukan proses evaluasi diri terhadap kelompok kerja yang berada dibawah tanggung jawabnya, dan mampu mengelola pembelajaran secara mandiri.

9. Mampu mendokumentasikan, menyimpan, mengamankan, dan menemukan kembali data untuk menjamin kesahihan dan mencegah plagiasi.

\section{d). Capaian Pembelajaran Bidang Keterampilan Khusus}

Lulusan Program Studi Ekonomi Syariah jenjang sarjana (level 6 dalam KKNI) wajib memiliki kekerampilan khusus sebagai berikut :

1. Terampil berwirausaha.

2. Terampil memasarkan produk.

3. Terampil membuat laporan keuangan.

4. Terampil berkomunikasi.

5. Terampil membaca fluktuasi harga produk pasar modal.

6. Terampil menganalisis kondisi perekonomian.

7. Terampil dalam metodologi penelitian.

8. Terampil dalam survey.

9. Terampil membuat studi kelayakan.

10. Terampil menggunakan teknologi. 
11. Terampil membuat perencanaan.

12. Terampil meminimalisir risiko.

13. Terampil berinteraksi.

14. Terampil membuat proposal.

15. Terampil membuat Rencana Anggaran Biaya.

16. Terampil membaca peluang.

17. Terampil membangun relasi jaringan.

18. Terampil mendisain produk.

19. Terampil memetakan konsumen.

20. Terampil mensimulasi perbankan syariah.

21. Terampil membuat sistim informasi akuntansi.

22. Terampil mensimulasi pasar modal syariah.

23. Terampil menguasai analisis teknikal dan fundamental.

\section{d. Pemetaan Bahan Kajian}

\begin{tabular}{|c|c|c|}
\hline No. & $\begin{array}{l}\text { Capaian } \\
\text { Pemhelaiaran }\end{array}$ & Bahan Kajian \\
\hline 1 & $\begin{array}{l}\text { Mampu menerapkan } \\
\text { pemikiran logis, kritis, } \\
\text { sistematis, dan inovatif dalam } \\
\text { konteks pengembangan atau } \\
\text { implementasi } \\
\text { pengetahuan dan teknologi } \\
\text { yang memperhatikan dan } \\
\text { menerapkan nilai humaniora } \\
\text { yang sesuai dengan keahlian. }\end{array}$ & $\begin{array}{l}\text { Ilmu-ilmu penelitian, } \\
\text { Teknologi dan Informasi, } \\
\text { logika, sosiologi, filsafat. }\end{array}$ \\
\hline 2 & $\begin{array}{l}\text { Mampu menunjukkan kinerja } \\
\text { mandiri, bermutu, dan } \\
\text { terukur. }\end{array}$ & $\begin{array}{lll}\text { Ilmu-limu } & \text { Islam, } & \text { Ilmu-ilmu } \\
\text { Ekonomi, } & \text { Fiqh, } & \text { Ilmu-ilmu } \\
\text { Keuangan, } & & \text { Ilmu-ilmu } \\
\text { manajemen } & & \end{array}$ \\
\hline
\end{tabular}




\begin{tabular}{|c|c|c|}
\hline 3 & $\begin{array}{lr}\text { Mampu mengkaji implikasi } \\
\text { pengembangan } \\
\text { implementasi } \\
\text { pengetahuan teknologi yang } \\
\text { memperhatikan } \\
\text { menerapkan nilai humaniora } \\
\text { sesuai dengan keahliannya } \\
\text { berdasarkan kaidah, tata cara } \\
\text { dan etika ilmiah dalam rangka } \\
\text { menghasilkan solusi, gagasan, } \\
\text { desain atau kritik seni, } \\
\text { menyusun deskripsi saintifik } \\
\text { hasil kajiannya dalam bentuk } \\
\text { skripsi atau laporan tugas } \\
\text { akhir, dan mengunggahnya } \\
\text { dalam laman perguruan } \\
\text { tinggi; menyusun deskripsi } \\
\text { saintifik hasil kajian tersebut } \\
\text { di atas dalam bentuk skripsi } \\
\text { atau laporan tugas akhir, dan } \\
\text { mengunggahnya dalam laman } \\
\text { perguruan tinggi. }\end{array}$ & $\begin{array}{l}\text { Filsafat, Metode Penelitian, } \\
\text { Bahasa, Teknologi } \\
\text { Informasi, Skripsi, Ekonomi, } \\
\text { Manajemen, Mikro dan } \\
\text { Makro, ekonomi, Statistik } \\
\text { dan Ekonometrika }\end{array}$ \\
\hline 4 & $\begin{array}{l}\text { Mampu menyusun deskripsi } \\
\text { saintifik hasil kajian tersebut } \\
\text { di atas dalam bentuk skripsi } \\
\text { atau laporan tuags akhir dan } \\
\text { mengunggahnya dalam laman } \\
\text { perguruan tinggi. }\end{array}$ & $\begin{array}{l}\text { Metode Penelitian, Bahasa } \\
\text { Indonesia, } \\
\text { Informasi, Skripsi } \\
\text { Indonesia, Bahasa } \\
\text { Skripsi) }\end{array}$ \\
\hline 5 & $\begin{array}{l}\text { Mampu mengambil keputusan } \\
\text { secara tepat dalam konteks } \\
\text { penyelesaian masalah di } \\
\text { keahliannya berdasarkan hasil } \\
\text { analisis informasi dan data. }\end{array}$ & $\begin{array}{lr}\text { Ekonometrika, } & \text { Statistika, } \\
\text { Manajemen, } & \text { Resiko, } \\
\text { Strategi, Pasar Modal, Bisnis }\end{array}$ \\
\hline
\end{tabular}




\begin{tabular}{|l|l|l|}
\hline 6 & $\begin{array}{l}\text { Mampu memelihara dan } \\
\text { mengembangkan jaringan } \\
\text { kerja dengan pembimbing, } \\
\text { kolega, sejawat baik di dalam } \\
\text { maupun di luar lembaganya; }\end{array}$ & $\begin{array}{l}\text { Manajemen, Komunikasi, } \\
\text { Bahasa, Sosiologi, Bisnis, } \\
\text { Entrepreneurship, Fiqh }\end{array}$ \\
\hline 7 & $\begin{array}{l}\text { Mampu bertanggungjawab } \\
\text { atas pencapaian hasil kerja } \\
\text { kelompok dan melakukan } \\
\text { supervisi dan evaluasi } \\
\text { terhadap penyelesaian } \\
\text { pekerjaan yang ditugaskan } \\
\text { kepada pekerja yang berada di } \\
\text { bawah tanggungjawabnya; }\end{array}$ & Manajemen, Strategi, Fiqh, \\
\hline 8 & $\begin{array}{l}\text { Mampu melakukan proses } \\
\text { evaluasi diri terhadap } \\
\text { kelompok kerja yang berada } \\
\text { dibawah tanggung jawabnya, } \\
\text { dan mampu mengelola } \\
\text { pembelajaran secara mandiri. }\end{array}$ & Pengantar Manajemen, Strategi, Bisnis, \\
Resiko, \\
\hline 9
\end{tabular}




\begin{tabular}{|c|c|c|}
\hline 12 & $\begin{array}{lr}\text { Memahami } & \text { pemasaran } \\
\text { produk, } & \text { memetakan } \\
\text { konsumen dan } & \text { terampil } \\
\text { berkomunikasi. } & \end{array}$ & $\begin{array}{l}\text { Ilmu-ilmu } \quad \text { Manajemen, } \\
\text { Komunikasi dan Teknologi }\end{array}$ \\
\hline 13 & $\begin{array}{l}\text { Mampu merencanakan strategi } \\
\text { bisnis. }\end{array}$ & Ilmu-ilmu Manajemen \\
\hline 14 & Mampu meminimalisir risiko. & $\begin{array}{l}\text { Ilmu-ilmu Manajemen dan } \\
\text { Risiko }\end{array}$ \\
\hline 15 & $\begin{array}{l}\text { Mampu menjalankan tata } \\
\text { kelola keuangan perusahaan. }\end{array}$ & $\begin{array}{l}\text { Ilmu-ilmu } \quad \text { Manajemen, } \\
\text { Sosiologi }\end{array}$ \\
\hline 16 & $\begin{array}{l}\text { Terampil berwirausaha dan } \\
\text { mampu } \\
\text { perancangan }\end{array}$ & $\begin{array}{lr}\text { Ilmu-ilmu } & \text { Bisnis, } \\
\text { Komunikasi, } & \text { Ilmu-ilmu } \\
\text { Manajemen, } & \text { Dasar-dasar } \\
\text { Mikro, Dasar-dasar Makro } & \text { dan Dasar-dasar Akuntansi }\end{array}$ \\
\hline 17 & $\begin{array}{l}\text { Mampu memahami akad-akad } \\
\text { dan produk perbankan } \\
\text { syariah. }\end{array}$ & Ilmu-ilmu Manajemen, Fiqh \\
\hline 18 & $\begin{array}{l}\text { Terampil membuat laporan } \\
\text { keuangan. }\end{array}$ & Ilmu-ilmu Akuntansi \\
\hline 19 & $\begin{array}{l}\text { Mampu memahami perilaku } \\
\text { pelaku ekonomi secara mikro. }\end{array}$ & $\begin{array}{l}\text { Ilmu-ilmu Ekonomi Mikro, } \\
\text { Ilmu Fiqh, Ilmu Islam }\end{array}$ \\
\hline 20 & $\begin{array}{l}\text { Memahami dan menganalisis } \\
\text { kondisi } \\
\text { makro/global perekonomian } \\
\text { makrolembaga dan kondisi } \\
\text { Islam serta mencari alternatif } \\
\text { jawaban masalah makro } \\
\text { ekonomi. }\end{array}$ & $\begin{array}{l}\text { Ilmu-ilmu Ekonomi Makro, } \\
\text { Sosiologi, Welfare }\end{array}$ \\
\hline
\end{tabular}




\begin{tabular}{|c|c|c|}
\hline 21 & \begin{tabular}{lcr} 
Memahami & kondisi & makro \\
ekonomi & dan & memberi \\
alternatif & solusi & untuk \\
\multicolumn{2}{l}{ berbagai kebijakan fiskal. }
\end{tabular} & Ilmu-ilmu Ekonomi Makro \\
\hline 22 & $\begin{array}{l}\text { Menguasai analisis } \\
\text { dan funnikal } \\
\text { mensimulasi pasar modal } \\
\text { syariah. }\end{array}$ & $\begin{array}{l}\text { Ilmu-ilmu Ekonomi (Makro } \\
\text { dan Mikro), Ilmu Akuntansi } \\
\text { Dasar, Ilmu Statistik Dasar, } \\
\text { Manajemen Keuangan }\end{array}$ \\
\hline 23 & Mampu membuat proposal. & $\begin{array}{l}\text { Ilmu-ilmu Ekonomi } \text { Makro, } \\
\text { Mikro, Akuntansi, Metode } \\
\text { Penelitian }\end{array}$ \\
\hline 24 & $\begin{array}{l}\text { Menerapkan rumus-rumus } \\
\text { matematika dalam mencari } \\
\text { solusi permasalahan ekonomi. }\end{array}$ & $\begin{array}{l}\text { Ilmu-ilmu Ekonomi, } \\
\text { Komunikasi, Sosiologi, Ilmu- } \\
\text { ilmu Agama }\end{array}$ \\
\hline 25 & $\begin{array}{l}\text { Mampu memahami dasar- } \\
\text { dasar mengidentifikasi dan } \\
\text { menganalisis data. }\end{array}$ & Ilmu-ilmu Statistik \\
\hline 26 & $\begin{array}{l}\text { Mampu melakukan tabulasi } \\
\text { data, survei, membuat } \\
\text { instrumen pengumpulan data, } \\
\text { mengolah data } \\
\text { mengintepretasi. }\end{array}$ & $\begin{array}{l}\text { Ilmu-ilmu Ekonomi (Mikro, } \\
\text { Makro, Akuntansi), } \\
\text { Komunikasi, Sosiologi, Ilmu- } \\
\text { ilmu Agama, Metode } \\
\text { Penelitian, Ilmu Statistik. }\end{array}$ \\
\hline
\end{tabular}




\begin{tabular}{|c|c|c|}
\hline 27 & $\begin{array}{lr}\text { Mampu menerapkan } \\
\text { penguasaan konsep ekonomi } \\
\text { konvensional dan ekonomi } \\
\text { syariah dalam melakukan } \\
\text { penilaian proses dan hasil } \\
\text { belajar ekonomi secara } \\
\text { sistematis } \\
\text { berkesinambungan dengan } \\
\text { memanfaatkan perkembangan } \\
\text { IPTEK dan menerpakan } \\
\text { metode-metode penelitian } \\
\text { dalam ilmu sosial, interpretasi } \\
\text { dan evaluasi data yang sesuai } \\
\text { dengan permasalahan yang } \\
\text { dihadapi. }\end{array}$ & $\begin{array}{l}\text { Ilmu-ilmu Statistik dan } \\
\text { Metode Penelitian, Bahasa, } \\
\text { Komunikasi. }\end{array}$ \\
\hline 28 & $\begin{array}{l}\text { Terampil membuat Studi } \\
\text { Kelayakan dan Rencana } \\
\text { Anggaran Biaya. }\end{array}$ & $\begin{array}{l}\text { Ilmu-ilmu Ekonomi (Mikro, } \\
\text { Makro, Akuntansi), Ilmu } \\
\text { Bisnis, Komunikasi, Ilmu- } \\
\text { ilmu Agama }\end{array}$ \\
\hline 29 & $\begin{array}{l}\text { Mampu memahami proses } \\
\text { bisnis dan lingkungan bisnis } \\
\text { syariah. }\end{array}$ & $\begin{array}{l}\text { Ilmu-ilmu Ekonomi, Filsafat, } \\
\text { Ilmu-ilmu Agama, Ilmu-ilmu } \\
\text { Bisnis }\end{array}$ \\
\hline 30 & $\begin{array}{lcc}\text { Mampu memahami dan } \\
\text { menghitung pajak-pajak. }\end{array}$ & Akuntansi, \\
\hline 31 & $\begin{array}{l}\text { Memahami kandungan Al- } \\
\text { qur'an dan Hadits berkenaan } \\
\text { dengan ekonomi. }\end{array}$ & Ilmu Islam \\
\hline 32 & $\begin{array}{l}\text { Memahami kaidah fikih dalam } \\
\text { mengambil keputusan di } \\
\text { bidang kebijakan lembaga } \\
\text { keuangan Islam. }\end{array}$ & $\begin{array}{l}\text { Ilmu-ilmu Fiqh dan Ilmu } \\
\text { Ekonomi }\end{array}$ \\
\hline 33 & Memahami ushul fikih & Ilmu Fiqh \\
\hline 34 & $\begin{array}{l}\text { Memahami landasan syariah } \\
\text { di lembaga keuangan. }\end{array}$ & $\begin{array}{l}\text { Ilmu-ilmu Ekonomi, Ilmu } \\
\text { Fiqh }\end{array}$ \\
\hline
\end{tabular}




\begin{tabular}{|c|c|c|}
\hline 35 & $\begin{array}{l}\text { Memahami asal muasal dan } \\
\text { sejarah Ekonomi Islam. }\end{array}$ & $\begin{array}{ll}\text { Ilmu Peradaban, } & \text { Ilmu } \\
\text { Ekonomi, Ilmu Agama } & \end{array}$ \\
\hline 36 & \begin{tabular}{lrr} 
Memahami & \multicolumn{2}{c}{ dasar-dasar } \\
ekonomi & Islam/ & filosofi \\
ekonomi Islam. &
\end{tabular} & $\begin{array}{l}\text { Ilmu Filsafat, Ilmu Ekonomi, } \\
\text { Ilmu Islam }\end{array}$ \\
\hline 37 & $\begin{array}{l}\text { Mampu membaca al-Qur'an } \\
\text { berdasarkan ilmu qira'at dan } \\
\text { ilmu tajwid secara baik dan } \\
\text { benar serta menghafal Al- } \\
\text { Quran Juz } 30 \text { (Juz Amma). }\end{array}$ & $\begin{array}{l}\text { Ilmu Qiraat, Ilmu Tajwid, } \\
\text { Fikih, Tahfiz }\end{array}$ \\
\hline 38 & $\begin{array}{llr}\text { Mampu } & \text { melaksanakan } & \text { ibadah } \\
\text { dan memimpin } & \text { ritual } \\
\text { keagamaan dengan } & \text { baik. } \\
\text { (Studi Hukum Islam). } & \end{array}$ & Fikih \\
\hline 39 & $\begin{array}{l}\text { Menguasai pengetahuan } \\
\text { tentang filsafat pancasila, } \\
\text { kewarganegaraan, wawasan } \\
\text { kebangsaan (nasionalisme) } \\
\text { dan globalisasi. }\end{array}$ & $\begin{array}{l}\text { Pancasila dan } \\
\text { Kewarganegaraan, Filsafat, } \\
\text { wawasan Kebangsaan }\end{array}$ \\
\hline 40 & $\begin{array}{l}\text { Menguasai proses dan } \\
\text { dinamika Islamisasi Kawasan } \\
\text { Melayu. }\end{array}$ & $\begin{array}{l}\text { Ilmu-Ilmu Islam, Peradaban, } \\
\text { Sosiologi }\end{array}$ \\
\hline 41 & $\begin{array}{l}\text { Menguasai pengetahuan dan } \\
\text { langkah-langkah integrasi } \\
\text { keilmuan (agama dan sains) } \\
\text { sebagai paradigma keilmuan. }\end{array}$ & $\begin{array}{l}\text { Ilmu-ilmu Islam, Ilmu Tafsir, } \\
\text { Ilmu-ilmu Pendidikan, Ilmu- } \\
\text { ilmu Sains }\end{array}$ \\
\hline
\end{tabular}




\section{e. Peta Kurikulum}

\begin{tabular}{|c|c|c|c|c|c|c|c|c|c|c|c|}
\hline \multirow{2}{*}{$\begin{array}{l}\mathrm{N} \\
\mathrm{O}\end{array}$} & \multirow{2}{*}{ Kode MK } & \multirow{2}{*}{ Mata Kuliah } & \multicolumn{9}{|c|}{ SEMESTER } \\
\hline & & & SKS & $\mathrm{I}$ & II II & II & IV & $\mathrm{V}$ & $\mathrm{VI}$ & $\mathrm{VII}$ & VII \\
\hline $1 \mathrm{~T}$ & UESY60001 & $\begin{array}{l}\text { Studi Al Qur'an \& } \\
\text { Hadist }\end{array}$ & 2 & 2 & & & & & & & \\
\hline $2 \pi$ & UESY60002 & Studi Hukum Islam & 2 & 2 & & & & & & & \\
\hline $3 \pi$ & UESY60003 & $\begin{array}{l}\text { Pendidikan Pancasila } \\
\text { \& Kewarganegaraan }\end{array}$ & 2 & 2 & & & & & & & \\
\hline 4 & UESY60004 & Bahasa Indonesia & 2 & 2 & & & & & & & \\
\hline 5 & UESY60005 & Bahasa Inggris & 2 & 2 & & & & & & & \\
\hline 6 & UESY60006 & Bahasa Arab & 2 & 2 & & & & & & & \\
\hline 7 & UESY60007 & Pemikiran Islam dan & 3 & 3 & & & & & & & \\
\hline 8 & UESY60009 & Islamic & 2 & 2 & & & & & & & \\
\hline 9 & UESY60010 & Kukerta & 4 & & & & & & 4 & & \\
\hline 10 & FESY61002 & Pengantar Ekonomi & 2 & 2 & & & & & & & \\
\hline 11 & FESY61001 & $\begin{array}{l}\text { Pengantar Akuntansi } \\
\text { Konvensional dan } \\
\text { Syariah }\end{array}$ & 3 & 3 & & & & & & & \\
\hline 12 & UESY60008 & $\begin{array}{l}\text { Islam dan Peradaban } \\
\text { Melayu }\end{array}$ & 2 & & 2 & & & & & & \\
\hline 13 & FESY63003 & Filsafat $\quad$ Ekonomi & 3 & & 3 & & & & & & \\
\hline 14 & FESY62004 & Ushul Fiqh & 2 & & 2 & & & & & & \\
\hline 15 & FESY61002 & \begin{tabular}{|lr} 
Ilmu Ekonomi & Mikro \\
Konvensional & dan
\end{tabular} & 4 & & 4 & & & & & & \\
\hline 16 & FESY62001 & Pengantar Manajemen & 2 & & 2 & & & & & & \\
\hline 17 & FESY62007 & Pengantar & 2 & & 2 & & & & & & \\
\hline 18 & FESY62002 & \begin{tabular}{|l|} 
Fiqh Keuangan \\
Kontemporer
\end{tabular} & 2 & & 2 & & & & & & \\
\hline 19 & FESY62003 & \begin{tabular}{|cc} 
Ayat dan & Hadits \\
Ekonomi
\end{tabular} & 2 & & 2 & & & & & & \\
\hline
\end{tabular}




\begin{tabular}{|c|c|c|c|c|c|c|c|c|}
\hline 20 & FESY62006 & Pengantar Bisnis & 2 & 2 & & & & \\
\hline 21 & FESY62005 & $\begin{array}{l}\text { Sejarah Pemikiran } \\
\text { Ekonomi Islam }\end{array}$ & 3 & 3 & & & & \\
\hline 22 & FESY63001 & $\begin{array}{l}\text { Islamic } \\
\text { Entrepreneurship }\end{array}$ & 4 & & 4 & & & \\
\hline 23 & ESY63001 & $\begin{array}{l}\text { Manajemen Keuangan } \\
\text { Islam }\end{array}$ & 3 & & 3 & & & \\
\hline 24 & FESY62002 & $\begin{array}{l}\text { Qowaidul Fiqhiyah Al- } \\
\text { Istishadiah }\end{array}$ & 2 & & 2 & & & \\
\hline 25 & FESY63002 & Statistik & 4 & & 4 & & & \\
\hline 26 & ESY64002 & $\begin{array}{l}\text { Studi Kelayakan } \\
\text { Bisnis Islam }\end{array}$ & 4 & & 4 & & & \\
\hline 27 & ESY62001 & $\begin{array}{lr}\text { Ilmu Ekonomi } & \text { Makro } \\
\text { Syariah } & \text { dan } \\
\text { Konvensional } & \end{array}$ & 4 & & 4 & & & \\
\hline 28 & ESY63002 & $\begin{array}{l}\text { Manajemen } \\
\text { Pemasaran }\end{array}$ & 2 & & 2 & & & \\
\hline 29 & ESY65002 & Manajemen Resiko & 3 & & & 3 & & \\
\hline 30 & ESY65001 & $\begin{array}{l}\text { Ekonomi } \\
\text { Kesejahteraan }\end{array}$ & 3 & & & 3 & & \\
\hline 31 & ESY65005 & $\begin{array}{l}\text { Kebijakan Fiskal dan } \\
\text { Moneter }\end{array}$ & 3 & & & 3 & & \\
\hline 32 & FESY64001 & $\begin{array}{l}\text { Matematika Ekonomi } \\
\text { dan }\end{array}$ & 4 & & & 4 & & \\
\hline 33 & ESY64003 & Ekonometrika & 3 & & & 3 & & \\
\hline 34 & ESY63004 & Etika Bisnis Islam & 3 & & & 3 & & \\
\hline 35 & ESY64008 & $\begin{array}{l}\text { Ekonomi } \\
\text { Pembangunan Islam }\end{array}$ & 3 & & & 3 & & \\
\hline
\end{tabular}


Implementasi Kurikulum KKNI...

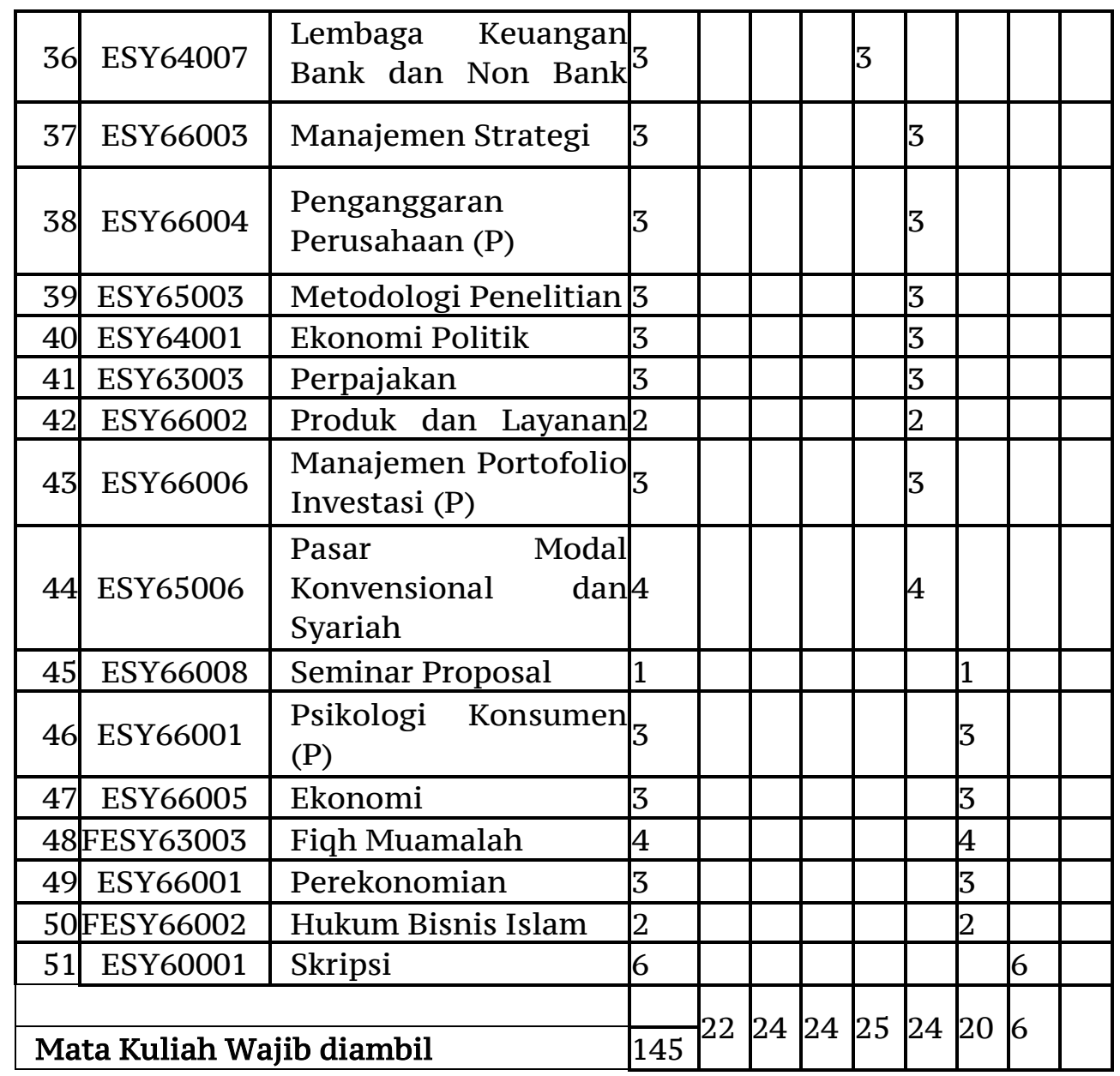

f. Salah Satu Sebaran Mata Kuliah Berdasarkan Profil Lulusan

(a) Entrepreneur Syariah

\begin{tabular}{|c|c|c|c|}
\hline No & $\begin{array}{c}\text { Kode } \\
\text { Mata } \\
\text { Kuliah }\end{array}$ & $\begin{array}{c}\text { M } \\
\text { a } \\
\text { t }\end{array}$ & SKS \\
\hline 1 & UESY60001 & Studi Al Qur'an \& Hadist & 2 \\
\hline 2 & UESY60002 & Studi Hukum Islam & 2 \\
\hline
\end{tabular}




\begin{tabular}{|c|l|l|c|}
\hline 3 & UESY60003 & Pendidikan Pancasila & 2 \\
\hline 4 & UESY60004 & Bahasa Indonesia & 2 \\
\hline 5 & UESY60005 & Bahasa Inggris & 2 \\
\hline 6 & UESY60006 & Bahasa Arab & 2 \\
\hline 7 & UESY60007 & Pemikiran Islam dan Filsafat & 3 \\
\hline 8 & UESY60008 & Islam dan Peradaban Melayu & 2 \\
\hline 9 & UESY60009 & Islamic Entrepreneurship & 4 \\
\hline 10 & UESY60010 & Kukerta & 3 \\
\hline 11 & FESY61001 & Pengantar Akuntansi Konvensional & 2 \\
\hline 12 & FESY61002 & Pengantar Ekonomi Mikro & 3 \\
\hline 13 & FESY62001 & Filsafat Ekonomi Islam & 2 \\
\hline 14 & FESY62002 & Ushul Fiqh & 4 \\
\hline 15 & FESY62003 & Ilmu Ekonomi Mikro Konvensional & 2 \\
\hline 16 & FESY62004 & Pengantar Manajemen & 2 \\
\hline 17 & FESY62005 & Pengantar Ekonomi Makro & 2 \\
\hline 18 & FESY62006 & Fiqh Keuangan Kontemporer & 2 \\
\hline 19 & FESY62007 & Ayat dan Hadits Ekonomi & 3 \\
\hline 20 & FESY62008 & Pengantar Bisnis & 4 \\
\hline 21 & FESY62009 & Sejarah Pemikiran Ekonomi Islam & 4 \\
\hline 22 & FESY63001 & Islamic Entreprenuership Lanjutan & 4 \\
\hline 23 & FESY63002 & Qowaidul Fiqhiyyah Al-Istishadiah & 2 \\
\hline 24 & FESY63003 & Statistik & 3 \\
\hline 25 & FESY64001 & Studi Kelayakan Bisnis Islam & 3 \\
\hline 26 & FESY64002 & Hukum Bisnis Islam & 3 \\
\hline 27 & FESY66001 & Fiqh Muamalah & 4 \\
\hline 28 & ESY63001 & Manajemen Keuangan Islam & 4 \\
\hline 29 & ESY63002 & Matematika Ekonomi dan Keuangan & 4 \\
\hline 30 & ESY63003 & Ilmu Ekonomi Makro Syariah dan & 4 \\
\hline 31 & ESY63004 & Manajemen Pemasaran & 2 \\
\hline 32 & ESY64001 & Manajemen Resiko & 2 \\
\hline 33 & ESY64002 & Ekonomi Kesejahteraan & 2 \\
\hline 34 & ESY64003 & Ekonometrika & 2 \\
\hline 35 & ESY64004 & Etika Bisnis Islam & 2 \\
\hline & & 2 \\
\hline
\end{tabular}




\begin{tabular}{|c|l|l|c|}
\hline 36 & ESY64005 & Lembaga Keuangan Bank dan Non & 3 \\
\hline 37 & ESY64006 & Kebijakan Fiskal dan Moneter & 3 \\
\hline 38 & ESY65001 & Manajemen Strategi & 3 \\
\hline 39 & ESY65002 & Peganggaran Perusahaan (P) & 3 \\
\hline 40 & ESY65003 & Metodologi Penelitian & 3 \\
\hline 41 & ESY65004 & Ekonomi Politik/Mgt Pembiayaan BS & 3 \\
\hline 42 & ESY65005 & Perpajakan & 3 \\
\hline 43 & ESY65006 & Produk dan Layanan Bank Syariah & 2 \\
\hline 44 & ESY65007 & Manajemen Portofolio Investasi (P) & 3 \\
\hline 45 & ESY65008 & Pasar Modal Konvensional dan & 4 \\
\hline 46 & ESY66001 & Seminar Proposal & 1 \\
\hline 47 & ESY66002 & Psikologi Konsumen (P) & 3 \\
\hline 48 & ESY66003 & Ekonomi Internasional & 3 \\
\hline 49 & ESY66004 & Perekonomian Indonesia & 3 \\
\hline 50 & ESY66005 & Ekonomi Pembangunan Islam & 145 \\
\hline & \multicolumn{2}{|}{ Jumlah } & \\
\hline
\end{tabular}

\section{Kesimpulan}

Dari kurikulum KKNI yang diimplementasikan berdasarkan temuan peneliti, dari 110 responden yang terdiri dari dosen di UIN baik dosen FEBI maupun dosen Fakultas lain yang ada di UIN STS Jambi, 88 persen mengatakan bahwa kurikulum KKNI yang telah diimplementasikan sudah baik, sedangkan sisanya 5 persen mengatakan belum baik, dan sisanya sebanyak 7 persen mengatakan tidak paham dengan kurikulum KKNI dalam arti tidak paham dimana bedanya dengan kurikulum sebelumnya bahkan mereka mengatakan tidak mengetahui berubahnya kurikulum.

\section{Daftar Pustaka}

Ahmad, dkk, Pengembangan Kurikulum, Bandung: CV. Pustaka Setia, 1998, h.10, h.14

Dakir. Perencanaan dan Pengembangan Kurikulum. Jakarta: PT.Rineka Cipta, 2004. 
Departemen Pendidikan dan Kebudayaan. Kamus Besar Bahasa Indonesia Edisi II. Jakarta: Balai Pustaka, 1990.

Direktorat Jendral Pembelajaran dan Kemahasiswaan, Kementerian Riset, Teknologi dan

Pendidikan Tinggi RI, Dokumen 001 KKNI, Ristek Dikti, 2015.

Direktorat Jendral Pembelajaran dan Kemahasiswaan, Kementerian Riset, Teknologi dan Pendidikan Tinggi RI.Panduan Penyusunan Kurikulum Pendidikan Tinggi, Ristek, 2016.

Harsono. Pengantar Problem-based Learning. Edisi kedua, MedikaFakultas Kedokteran. Universitas Gadjah Mada, 2005.

Murray Print. Curriculum development and design (second edition). Sidney: Allen \& Unwin, 1992.

Khun, Thomas, The Structure of Scientific Revolution. $3^{\text {rd }}$ ed. Chicago, IL: University of Chicago Press, 1996.

Tohirin. Metode Penelitian Kualitatif Dalam Pendidikan dan Bimbingan Konseling. Jakarta: PT Rajagrafindo Persada, 2012.

Unguh, Jasa. Metode Penelitian Pendidikan dengan Studi Kasus. Yogyakarta: Gava Media, 2014.

Peraturan Menteri Pendidikan dan Kebudayaan Republik Indonesia Nomor 49 Tahun tentang Standar Nasional Pendidikan Tinggi. 2014

Prideux D. $A B C$ of leraning and teaching in medicine: Curriculum design. BMJ 2003. 